\title{
RISK MANAGEMENT DURING OUTAGE PROJECTS AT POWER PLANTS
}

\author{
S.C. Hlophe ${ }^{1}$ \& J.K. Visser ${ }^{1 *}$
}

\section{ARTICLE INFO}

Article details

Presented at the $29^{\text {th }}$ annual conference of the Southern African Institute for Industrial Engineering (SAIIE), held from 24-26 October 2018 in Stellenbosch, South Africa

Available online 9 Nov 2018

Contact details

Corresponding author krige.visser@up.ac.za

Author affiliations

1 Department of Engineering and

Technology Management,

University of Pretoria, South Africa

DOI

http: / /dx.doi.org/10.7166/29-3-2051
ABSTRACT

Outages are needed for the maintenance of most continuously operated plants such as power plants, refineries, and petrochemical plants. Such plants comprise thousands of items of complex equipment and machinery that operate under rigorous operating conditions. Tasks carried out during outage projects include overhauls, inspections, repairs, replacement of equipment, and modification. Like most complex projects, outage projects have a high risk that there will be cost and schedule overruns. A study was done to investigate the management of risks in outage projects at South African power plants. The main objective was to determine whether project risk management is understood and recognised as a success factor for outage projects. A conceptual framework developed from the literature was used to design a survey questionnaire that was emailed to potential respondents who are involved in the management of outage projects. The results of the survey indicated that ineffective or weak outage risk management often results in large cost and schedule overruns. Effective planning and risk management were identified as the most important success factors for outage projects. The study identified training in risk management, an enabling culture, and management support as areas for improvement in outage project risk management.

\section{OPSOMMING}

Lang onderbrekings is nodig om instandhouding te doen by aanlegte wat kontinu bedryf word, soos kragstasies, raffinaderye en chemiese aanlegte. Sulke aanlegte het dikwels duisende komponente wat volgens voorgeskrewe prosedures bedryf word. Take tydens afsluiting behels byvoorbeeld opknapping, inspeksie, herstel, vervanging en modifikasie. Soos met die meeste komplekse projekte het afsluitingsprojekte ook ' $\mathrm{n}$ groot risiko dat dit nie binne begroting en skedule voltooi kan word nie. 'n Studie is uitgevoer om die bestuur van risiko's tydens afsluitingsprojekte by SuidAfrikaanse kragaanlegte te ondersoek. Die vernaamste doelwitte van die studie was om te bepaal of projek risikobestuur verstaan word en erken word as 'n kritiese suksesfaktor vir afsluitingsprojekte. 'n Konseptuele model is ontwikkel met behulp van 'n literatuurstudie en gebruik om 'n meningsopname te ontwikkel. Die vraelys is aan potensiële respondente gestuur wat betrokke is by die bestuur van afsluitingsprojekte. Die resultate van die opname het getoon dat oneffektiewe of swak risikobestuur dikwels lei tot groot oorspandering en glip op die skedule van die projek. Effektiewe beplanning en risikobestuur is geïdentifiseer as die belangrikste suksesfaktore vir afsluitingsprojekte. Die studie het ook aangedui dat opleiding in risikobestuur, 'n positiewe werkskultuur en bestuurshulp vir risikobestuur van afsluitingsprojekte areas vir verbetering is. 


\subsection{Background}

Outage (shutdown) management is one of the strategies used in continuous production process plants such as power plants, refineries, and petrochemical plants to maintain their physical assets. Such plants comprise thousands of items of complex equipment and machinery that run under rigorous operating conditions. Tasks carried out during shutdown projects include overhauls, maintenance, inspections, repairs, replacement of equipment, modification, and upgrade projects. Outages are known for high levels of risk, with a large potential for cost and schedule overruns. The management of risks and uncertainty is seen as essential for outage project success. Researchers have studied risk management in all type of projects, including engineering, construction, and mega-projects. However, not much research has been done on the risk management of outage projects.

South Africa's commercial power-generating plants are owned, managed, and operated by Eskom, a state-owned power utility company. Eskom is the primary electricity producer, accounting for about 95 per cent of all electricity produced in South Africa and about 45 per cent on the African continent. The power utility is one of the top 20 utilities in the world in terms of generating capacity. Its mandate is to provide electricity in an efficient and sustainable manner. For this mandate to be realised, power stations must have a high availability and good reliability.

\subsection{Outage management in Eskom}

Two of the main challenges facing Eskom are of interest to this study. These challenges are (1) declining plant performance and increases in unplanned shutdowns; and (2) the unavailability of space in the work schedule for planned outages. The latter challenge means that power plants operate at high levels of risk, which often lead to unplanned outages and to running with continuous partial load losses, as the time needed to maintain the plant properly is not available. The main mandate of technology outage management is to provide an end-to-end outage management service that is standardised across the entire organisation, with a focus on high quality and on-time completion. 'Focus on high quality' refers to having the plant more reliable and available after an outage project is completed, while 'on-time completion' is normally referred to as 'due-date performance' (DDP).

Eskom's technology outage management has been under much pressure and scrutiny lately as the utility has battled to supply power consistently to South African industries, municipalities, and communities. Continuous load-shedding had caused many stakeholders, including political parties in Parliament, to be dissatisfied with the organisation's ability to offer reliable service to all South Africans. Rolling black-outs have arisen because of capacity not being available during times of peak demand, mainly due to plant breakdowns (unplanned outages) and planned plant interventions. The sustainability of electricity generation is largely dependent on having capacity available when it is needed - which means a reduction in plant breakdowns, and planned shutdowns being completed on time, with no unplanned capacity loss factor (UCLP) after the unit is synchronised on load. For generation businesses to achieve their goal, it is crucial that group technology outage management delivers on its mandate. Outage management will always be under severe pressure to execute agreed outages within the shortest possible time, by meeting the agreed/frozen statement of work (SOW) within the reliability, quality, and financial interests of Eskom.

\section{LITERATURE REVIEW}

A literature review was conducted to identify trends that have emerged in the knowledge area of project risk management [1]. The literature was used to develop an analytical framework for analysing primary data. Lenahan [2] said that shutdown management projects have not been given much attention by researchers, despite the significant impact they have on organisations. Poor management of outages could disadvantage a company's competitiveness. Properly managed outage projects could have major benefits for industries such as oil and gas, petrochemicals, and utilities. The methodology is also relevant in other sectors whose degree of sophistication might be less; but benefits might also be realised when large losses in production are incurred due to unnecessary downtime [2]. A shutdown management project is a combination of maintenance management, construction, installation, inspection and testing, and other projects in the same period [3]. 
Project risk management practices are still not widely applied in South African engineering and construction projects [4]. Risk management in projects involves the analysis of the objective function of the project interaction with its environment [5]. It is not enough to define a project in terms of schedule, budget, and quality [5]: it is also necessary to take a holistic perspective. Risk management must be integrated with all the variables involved in the environment. The Treasury Board of Canada Secretariat defines 'integrated risk management' as a continuous, proactive, and systematic method to understand, manage, and communicate risk organisation-wide [6]. Risks require a strategy of early diagnosis and management [7] and proactive project risk management [8].

Risk and uncertainty is inherent in all types of projects [4] due to complexity and restrictions in time, cost, and resources 9]. It has the potential to endanger the ability of the project manager and team to meet project objectives. Project complexity and uncertainty requires greater flexibility and reflection [9] to understand risk origin to a different extent in all types of projects. Risk management in projects has gained much attention from scholars and researchers, but there is still considerable room for development in the field [9]. Atkinson, Crawford and Ward [10] see the management of risk and uncertainty as a necessary condition for effective project management, since sources of uncertainty are wide-ranging and can influence projects. Conventional project management is lacking in risk management, and is too focused on operational planning and control. Atkinson et al. [10] identify three areas of uncertainty: in estimates, project stakeholders, and stages of the project life cycle.

Outage maintenance strategies have emerged as a critical management decision to achieve optimal output for a unit or plant while adhering to safety and regulatory requirements and reduced overall costs [11]. Barber [12] identified a class of risk that is common, important, and yet poorly managed in projects. He stated that internally generated risks arise within project management teams or organisations from their management systems, culture, and decisions. Failure to implement sound risk management systems in projects results in high financial losses to organisations. Project risk is a threat to project success where the final impact upon project success is not certain [12]. It implies that risks arise because of uncertainty in projects. A shutdown project's scope of work is mainly determined by plant and equipment inspections, normally performed once the plant is off-line. However, it is often difficult to finalise and freeze the scope on time, as is the norm in most engineering and construction projects. High levels of uncertainty about unanticipated findings during inspections make shutdown projects even riskier than other projects. Shutdowns are special projects that require a specialised level of management on all aspects of project management, including scope, integration, cost, time, and procurement. Most activities performed during shutdowns are outsourced by organisations because of the high labour intensity that they do not themselves have available, and the complexity of the total project.

A shift to strategy-based project management and to the real-time management of risks, uncertainties, and opportunities is required [13]. Risk analysis and management should not be a separate planning and response operation. Risks and uncertainty will always be inherent in complex projects in a dynamic environment. There is a difference between anticipated but uncertain risks, and unexpected events caused by environment dynamism [14]). In outages, the risk in scope resulting from inspections can be anticipated, but the outcome of inspections is less certain. Understanding and managing risks in large engineering projects is a challenging task [15]. Largescale engineering projects have high risks that are characterised by substantial and irreversible commitments.

According to Elkington and Smallman [16], business risks may affect the delivery of the benefits to be gained by undertaking a project, and there is a weak relationship between the amount of project risk and the level of risk management in projects. They also found a correlation between the levels of risk management undertaken in a project and the success rate of projects. Chihuri and Pretorius [4] identified risk management training as a key element for successful project risk management, as it creates understanding and awareness about successful implementations by project teams. Competence in project managers and project teams in project management and risk management could improve the awareness and practice of risk management in projects. Du Plessis [17] agrees that one of the reasons that projects fail is that the people who should be involved are not involved. Stakeholders have always been associated with making or breaking projects; and a lack of stakeholders' involvement and buy-in from the beginning of projects can jeopardise the achievement 
of project objectives. De Bakker et al. [18] identified key elements in the risk management process to include the stakeholders' perception of risk and success, and their behaviour.

\section{THEORETICAL FRAMEWORK}

A model to measure the impact of risk management on the engineering and construction projects environment in South Africa, proposed by Chihuri and Pretorius [4], was adapted (Figure 1 below). This conceptual model for project risk management was used to design the questionnaire that gathered data for the research project.

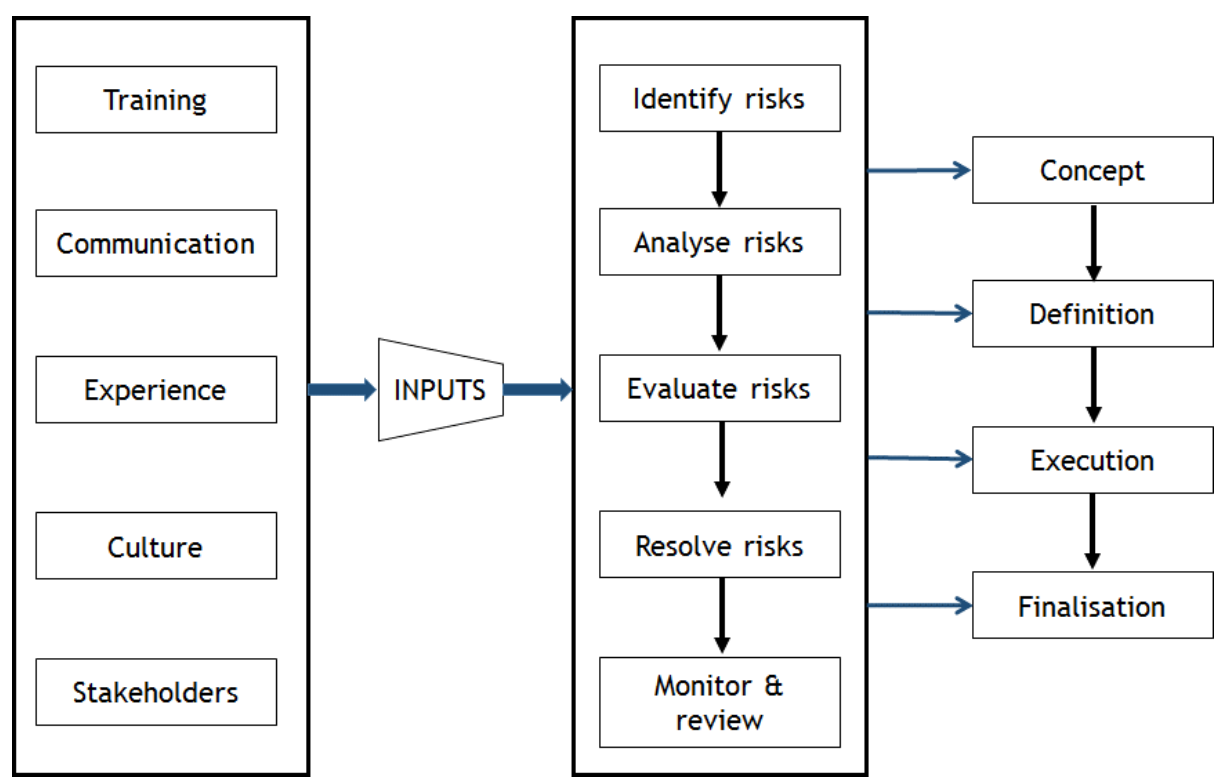

Figure 1: Conceptual model for outage risk management

At the centre of the model is the project risk management process used in the Smith and Merritt [8] and PMBOK [19] frameworks. The left-hand side of the model represents the project life-cycle model adopted by Eskom outage management for their shutdown projects. Critical elements for effective project risk management are presented as inputs on the left-hand side of the model. These are training, communication, lessons learnt from experience, organisational culture, and stakeholders. These were all informed by the literature review presented in section 2 .

\section{RESEARCH METHODOLOGY}

The research approach comprised an exploratory research and literature review, coupled with a survey questionnaire distributed to potential respondents who are involved in the day-to-day management and execution of power plant outage projects. The questionnaire design was based on the conceptual model presented in section 3 above. It comprised 32 questions; 31 of them were closed questions, while one was an open-ended question. Most of the questions used a five-point Likert scale ranging from ' 1 ', 'strongly disagree', to ' 5 ', 'strongly agree'. The methodology involved the following steps:

- A literature review to identify issues that are potentially crucial in effective project risk management

- Desk research to review secondary data on the trends and current performance of Eskom outage management

- Development of a conceptual framework

- Development of a survey questionnaire for distribution to outage management employees as potential respondents

- Analysis of responses and results 


\section{- Conclusion and recommendations}

The survey link containing the questionnaire was distributed by email to potential respondents in outage management in coal-fired power stations. Some 85 questionnaires were distributed, and 61 completed questionnaires were returned. Of the respondents, $20 \%$ were managers, $3 \%$ senior advisors, $13 \%$ planners, $43 \%$ outage coordinators, and 21\% 'other'. The 'other' group represented those providing supporting resources to outage management: quality control officers, seconded resources that are not part of the permanent structure, quality engineers, spares coordinators, and contracts managers.

\section{RESULTS}

\subsection{Survey responses}

All of the respondents who completed the survey were involved in outage projects management within their respective power stations. All 13 Eskom coal-fired power stations were represented. The two partially completed power stations, Medupi and Kusile, were not part of the survey. The email addresses of potential respondents were obtained from the organisation's personnel database.

\subsubsection{Years of experience}

About $63 \%$ of the respondents had less than five years' experience in outage projects, while about $6 \%$ had more than 16 years' experience. This indicated that the project teams involved in outage projects were young and had much to learn within such projects. Most of the respondents had worked for some years within the organisation, but had performed other functions such as maintenance, operations, and engineering.

\subsubsection{Project and risk management training}

The results indicated that only $75 \%$ and $60 \%$ of the respondents are trained in project management and risk management respectively. Outage management projects are characterised by high level of uncertainty, and more effort is required to provide risk management training for younger team members. A high level of competency is needed in the outage environment, where staff should be skilled in project and risk management.

\subsubsection{Time spent on project risk management}

Figure 2 below shows a comparison of the time that the respondents spent on project risk management in their current job functions. This is a comparison between managers, coordinators, and planners.

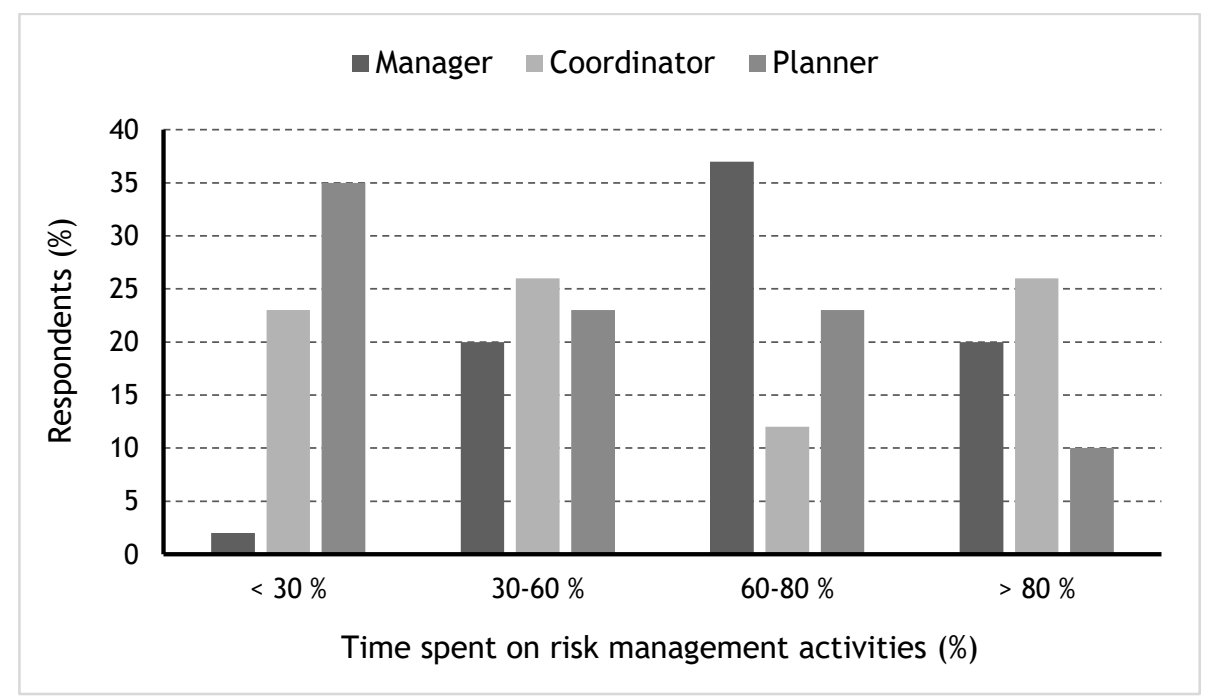

Figure 2: Time spent on risk management

From Figure 2, it can be seen that some planners spend more than $80 \%$ of their time on risk management. This is surprising, as they are not expected to manage high-level risks on a daily basis. 
Most managers in fact spend between 60 and 80 per cent of their time on project risk management. The time spent by coordinators on risk management activities varies from $<30 \%$ to $>80 \%$.

\subsubsection{General risk management and process-related issues}

Respondents were asked to indicate their level of agreement with eight statements related to the management of outage projects, reflected in Figure 3 below. The 'strongly agree' and 'agree' responses were grouped together to obtain a total number as a percentage of the number of respondents.

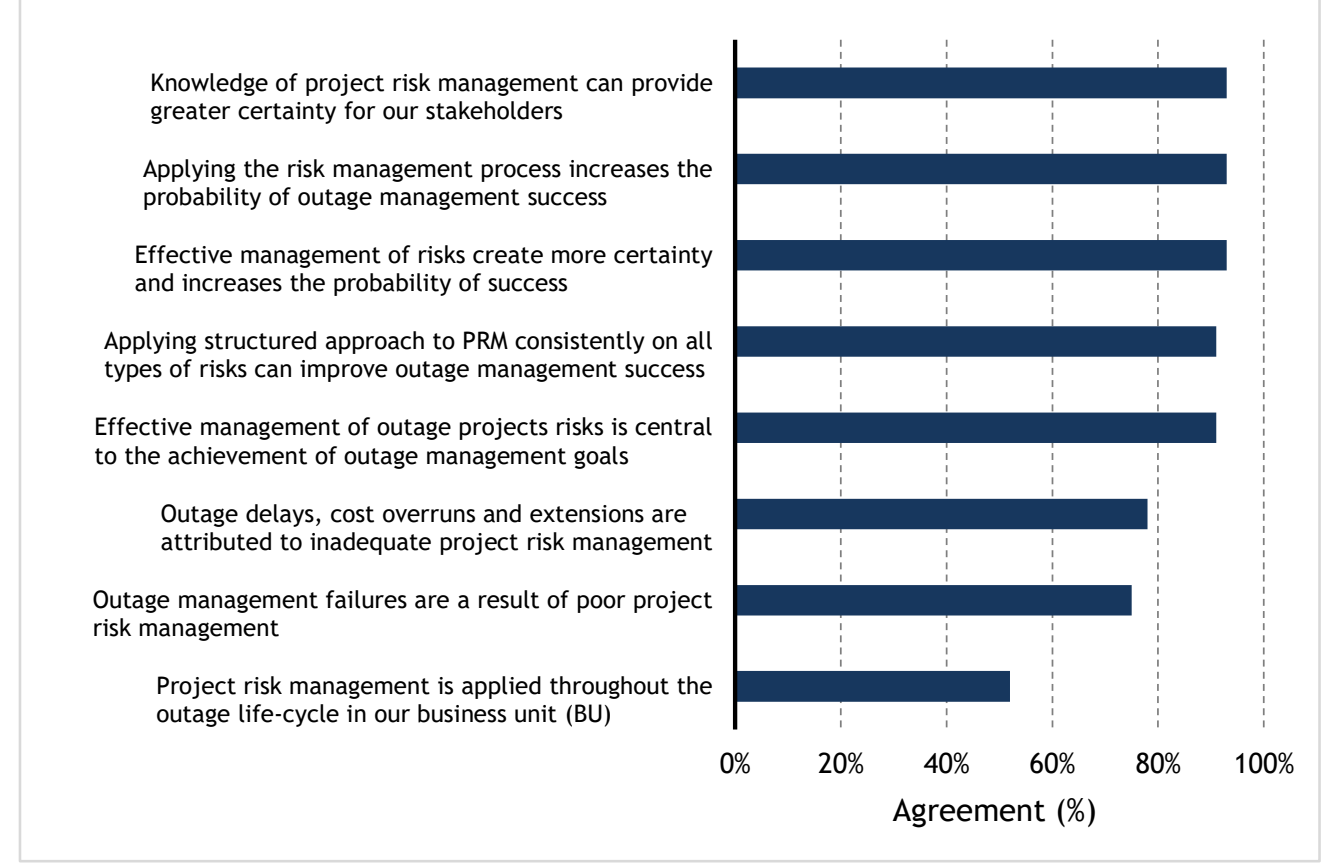

Figure 3: Agreement with statements on project risk management

As shown in Figure 3, more than $90 \%$ of the respondents agreed that the effective management of outage risks is essential, and increases the chance of success. They were also in agreement that applying a structured approach to project risk management and the application of the risk management process improves the chance of success. More than $70 \%$ of the respondents agreed that outage management failures are a result of poor project risk management and that delays, cost overruns, and extensions are due to inadequate project risk management.

Although project risk management is well understood within the outage management community, only $52 \%$ of the business units apply risk management throughout the outage life-cycle. This is a matter of significant concern, considering the number of unsuccessful outages and extensions to outage due dates within the organisation. For project risk management to be successful, it must be consistently applied across the outage life-cycle in all business units to improve the business. The outage life-cycle process is meant to eliminate uncertainty during outage execution. It poses a threat to outage management success if $48 \%$ of the respondents do not apply risk management throughout the outage life-cycle in their business units.

\subsubsection{Project risk management process compliance}

Six statements related to risk meetings, risk identification, risk assessment, risk prioritisation, risk ranking, risk monitoring and review, and whether contingencies are planned for the risks that were indentified in the questionnaire. The respondents' levels of agreement with these statements are shown in Figure 4.

Some $69 \%$ of the respondents agreed that risk management meetings are held throughout the outage life-cycle where risks are identified, analysed, evaluated, and resolved. More than $70 \%$ of the respondents agreed that risks are assessed and ranked according to their likelihood and overall impact on cost and schedule in their business units. Some $74 \%$ of the respondents agreed that 
contingency plans for time and budget are developed for all significant identified risks. They also agreed $(78 \%)$ that identified risks are prioritised, based on impact, probability, and urgency. Some $85 \%$ of the respondents agreed that risk monitoring and review is continuous across all phases of an outage life-cycle.

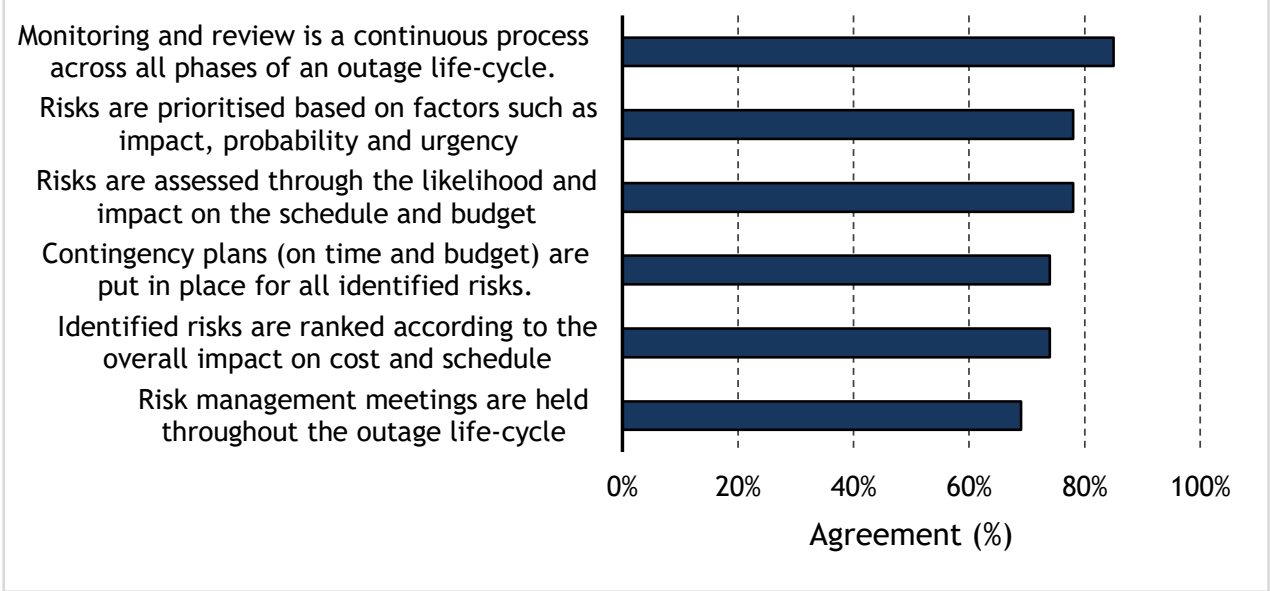

Figure 4: Agreement with statements on the project risk management process

Considering the results for this section of the questionnaire, it can be concluded that risk management compliance is at an acceptable level, although it is better to have a level of agreement above $90 \%$ for all aspects mentioned in the questionnaire. The results support the finding that $40 \%$ of the respondents did not have risk management training, which makes the whole process somewhat ineffective. It can also be stated that the project risk management process is generally understood within Eskom outage management. Training plays a key role in ensuring that staff are knowledgeable, to make the whole process more effective. Lack of risk management training could result in poor risk identification, analysis, and evaluation, as well as poor risk monitoring and review. Much effort might be spent on trying to mitigate risks, only to find that some of these were minor risks.

\subsubsection{Risk management process effectiveness in various business units (BUs)}

Respondents were asked to indicate the effectiveness of the risk management process in their BUs. Five responses were provided: 'not effective', 'slightly effective', 'somewhat effective', 'effective', and 'highly effective'. The results are indicated in Figure 5.

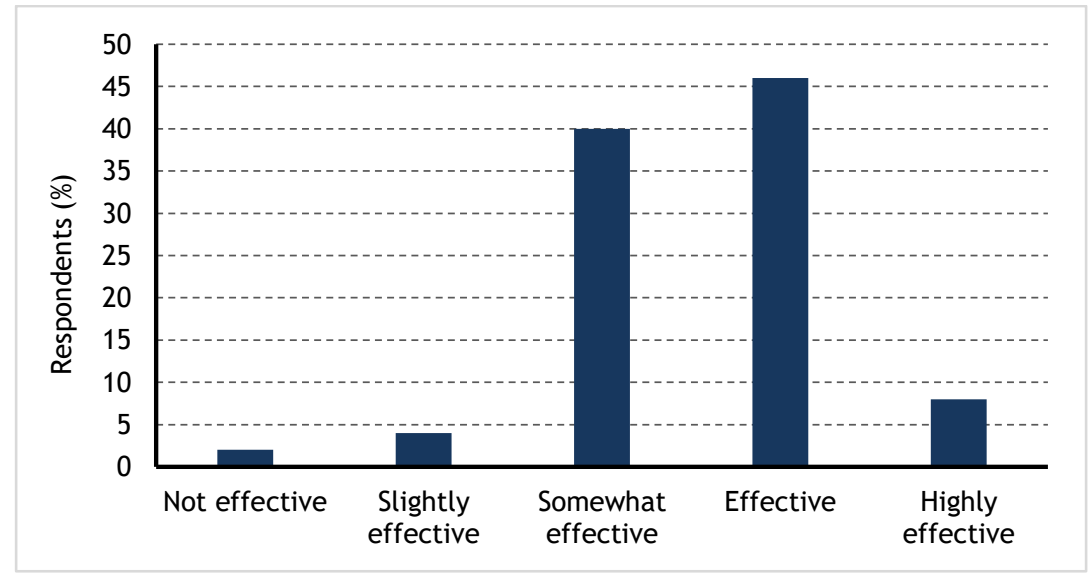

Figure 5: Effectiveness of risk management processes

About $50 \%$ of the respondents indicated that the process is effective or highly effective. However, it is concerning to note that $40 \%$ were uncertain about whether or not their risk management process 
is effective. This correlates with the finding that $40 \%$ of them were not trained in project risk management.

\subsubsection{Critical factors for outage management success}

Respondents were asked to select three factors from a pre-defined list that they consider to be very important for outage management success. The factors were then ranked according to the number of selections by each respondent. Figure 6 below shows the factors that were selected most often.

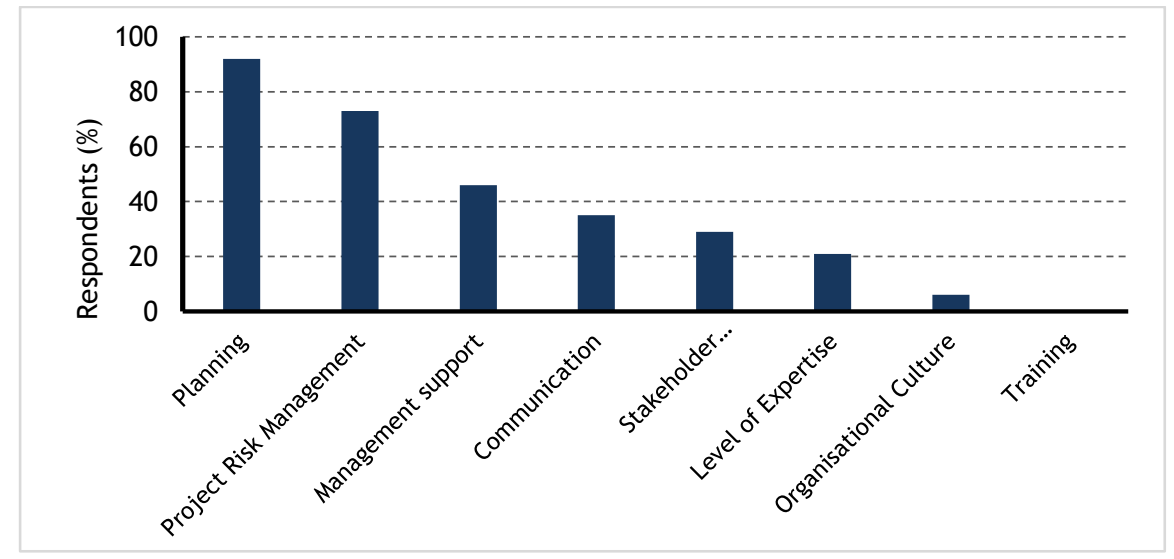

Figure 6: Identified success factors from pre-determined list

Figure 6 shows that planning, risk management, and management support were the top three factors that determine outage project success. This is one of the most important findings from the survey. One reason that 'planning' was ranked the highest could be attributed to the outage management life-cycle process, which puts a greater emphasis on preparation and planning.

Risk management, ranked second-highest, shows that project risk management is widely recognised as one of the critical success factors for outages; and this answers one of the research questions i.e., "Is risk management recognised within Eskom outages as a success factor for projects?"

Respondents were also asked to identify three factors that are critical to outage management success, based on their work experience. No pre-identified factors were provided for this question; respondents were given an opportunity to state their point of view on this question. In total, 20 factors were identified by the survey's respondents. These are presented in Figure 7.

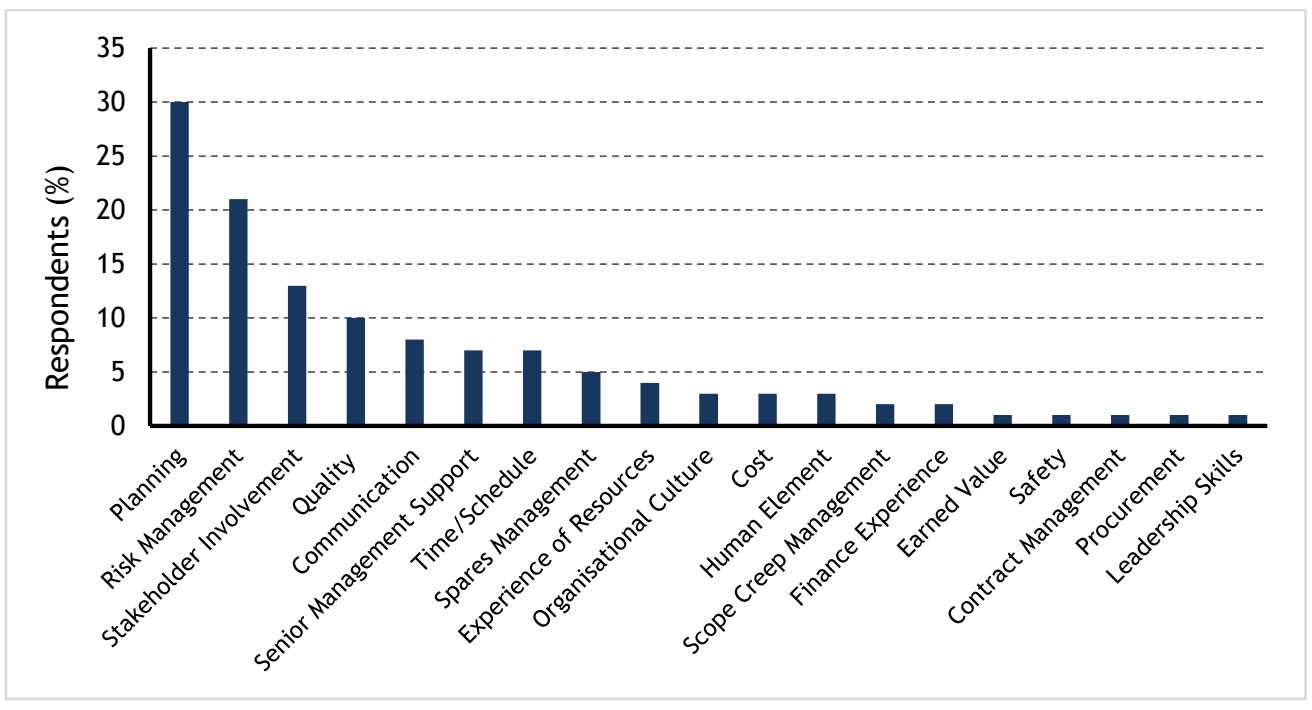

Figure 7: Critical success factors identified in an open question 
Once again it is seen that planning and risk management were ranked the highest, as was the case in Figure 6. This confirms that project risk management is widely acknowledged to be a success factor in achieving outages project success.

\section{CONCLUSIONS AND RECOMMENDATIONS}

\subsection{Conclusions}

The findings of this study show that project risk management process and practice is well understood within Eskom's outage management. However, the level of compliance is still not acceptable. Although many power stations embrace the principles of project risk management, they are still not consistently applied throughout the entire outage management life-cycle process. The findings also reveal that project risk management is widely recognised as a success factor in outage management. Eskom's outage management does manage risks in outage projects; however, it is still not at the level that would enhance and sustain positive performance. Most shutdowns fail due to nonadherence to project risk management practices. Understanding the probability of risks occurring, and being able to evaluate their probability, severity, and criticality requires a great degree of experience and knowledge. Thus training and experience play major roles in ensuring the effectiveness of the risk management process. Organisations should be prepared to commit time and money to building capacity in and knowledge of project risk management.

\subsection{Recommendations}

The research identified the need for outage management to build capacity for effective project risk management. The experience of employees play a crucial role in proactively identifying and anticipating risks in projects. More outage management employees need to be trained in project management and risk management. This can ensure sustainable and positive outcomes for Eskom's outage management community.

There are some inconsistencies in how project risk management is applied across the outage lifecycle in the BUs. The outage centre of excellence needs to put measures in place to facilitate effective project risk management across all BUs. This will create more certainty, and improve the probability of outage projects success. The centre of excellence should employ an outage risk manager at a middle-management level whose responsibility would be to ensure standardised project risk management across all BUs.

Supportive organisational culture also plays a major role in the success or failure of any organisational process-related initiative. Organisations should conduct culture surveys to evaluate whether the culture supports organisational goals. The results should be used to address identified gaps in outage performance.

The sample size of 61 represented only Eskom's outage management employees. It is recommended that a similar study be conducted soon to include respondents from partner organisations that contract with Eskom's outage management. Future research can also be done to cover outage projects in South African organisations such as petrochemical plants and refineries.

\section{REFERENCES}

[1] Smallbone, T. \& Quinton, S. 2011. A three-stage framework for teaching literature reviews: A new approach. The International Journal of Management Education, 9(4), pp 1-11.

[2] Lenahan, T. 2011. Turnaround shutdown and outage management: Effective planning and step-by-step execution of planned maintenance and operations. $2^{\text {nd }}$ ed. Butterworth-Heinemann. Oxford.

[3] Obiajunwa, C.C. 2013. Skills for the management of turnaround maintenance projects. Journal of Quality in Maintenance Engineering, 19(1), pp. 61-73.

[4] Chihuri, S. \& Pretorius, L. 2010. Managing risk for success in South African engineering and construction project environment. South African Journal of Industrial Engineering, 21(2), pp. 63-77.

[5] Sanchez, H., Robert, B., Bourgault, M., \& Pellerin, R. 2009. Risk management applied to projects, programs, and portfolios. International Journal of Managing Projects in Business, 2(1), pp. 14-35.

[6] Treasury Board of Canada Secretariat. 2010. Guide to Integrated Risk Management (Available from: https: / /www.canada.ca/en/treasury-board-secretariat/corporate/risk-management/guide-integratedrisk-management.html\#toc2_1) 
[7] Aloini, D., Dulmin, R. \& Mininno, V. 2007. Risk management in ERP project introduction: Review of the literature. Information and Management Journal, 44, pp. 547-567.

[8] Smith, P.G. \& Merritt, G.M. 2002. Proactive risk management: Controlling uncertainty in product development. Productivity Press. New York.

[9] Perminova, O., Gustafsson, M. \& Wikström, K. 2007. Defining uncertainty in projects - a new perspective. International Journal of Project Management, 26, pp. 73-79.

[10] Atkinson, R., Crawford, L. \& Ward, S. 2006. Fundamental uncertainties in projects and the scope of project management. International Journal of Project Management, 24(8), pp. 687-698.

[11] Hameed, A. \& Khan, F. 2014. A framework to estimate the risk-based shutdown intervals for a processing plant. Journal of Loss Prevention in the Process Industries, 32, pp. 18-29.

[12] Barber, R. 2005. Understanding internally generated risks in projects. International Journal of Project Management, 23, pp. 584-590.

[13] Jaafari, A. 2001. Management of risks, uncertainties and opportunities on projects: Time for a fundamental shift. International Journal of Project Management, 19, pp. 89-101.

[14] Floricel, S. \& Miller, R. 2001. Strategizing for anticipated risks and turbulence in large-scale engineering projects. International Journal of Project Management, 19, pp 445-455.

[15] Miller, R. \& Lessard, D. 2001. Understanding and managing risks in large engineering projects. International Journal of Project Management, 19, pp. 437-443.

[16] Elkington, P. \& Smallman, C. 2002. Managing project risks: A case study from the utilities sector. International Journal of Project Management, 20, pp. 49-57.

[17] Du Plessis, Y. 2014. Project management: A behavioural perspective. Cape Town: Pearson Publishers.

[18] De Bakker, K. Boonstra, A. \& Wortmann, H. 2010. Does risk management contribute to IT project success? A meta-analysis of empirical evidence. International Journal of Project Management, 28, pp. 493-503.

[19] Project Management Institute (PMI). 2013. A guide to project management body of knowledge. $5^{\text {th }} \mathrm{eEd}$. Upper Darby, PA: 19082 USA. 